\section{Biochar Rate and Transplant Tray Cell Number Have Implications on Pepper Growth during Transplant Production}

\author{
Ajay Nair ${ }^{1,3}$ and Brandon Carpenter ${ }^{2}$
}

AdDITIONAL INDEX WORDs. Capsicum annuum, growing medium, potting mix, sphagnum peatmoss, seedling germination, transplant dry weight

SUMMARY. Biochar, a carbon-rich material derived from the pyrolysis of organic matter, exhibits beneficial chemical and physical properties when added to a soilless medium. Research on the use of biochar to improve plant productivity and growth has increased over the past decade, and has focused on using biochar as an alternative to sphagnum peatmoss. However, little work has been done to determine whether biochar can be used to partially replace commercially available sphagnum peatmoss-based greenhouse medium in vegetable transplant production. This study investigated the potential for supplementing a greenhouse growing medium with biochar for 'Paladin' pepper (Capsicum annumm) transplant production. Biochar was added to a soilless mix at rates of $0 \%, 20 \%, 40 \%, 60 \%$, or $80 \%$ (by weight). Pepper seedlings were grown for 56 days in 50-, 72-, or 98-cell transplant trays at each of the five levels of biochar concentration. Germination increased in the 50and 72 - cell trays with $20 \%, 40 \%$, and $60 \%$ biochar; however, biochar had no effect on germination in the 98-cell tray. Seedling height and dry weight decreased as biochar concentration and cell number increased. Seedling stem diameter also decreased with increasing cell number and biochar concentration. Leaf SPAD readings (indirect measurement of chlorophyll) decreased with increasing biochar rate. Medium $\mathrm{pH}$ increased with increasing biochar application rates. Higher rates of biochar $(60 \%$ and $80 \%)$ increased $\mathrm{pH}$ well beyond 7.0 and negatively affected transplant growth. Overall results indicate positive effect of biochar in sphagnum peatmoss-based growing mix on seedling growth characteristics; although higher biochar concentrations could negatively affect seedling growth. Biochar can successfully replace up to $40 \%$ of sphagnum peatmoss-based growing medium and serve as a sustainable alternative medium in vegetable transplant production.

$\mathrm{P}$ epper is an important vegetable crop in the United States with 44,800 acres planted annually (U.S. Department of Agriculture, 2016). Pepper crops are established using transplants since transplants are uniform in size, increase earliness, and decrease production costs associated with thinning of seedlings in the field (Biai et al., 2011; Schrader, 2000). In the transplant production phase, growing medium plays an important role in plant health. Most growers use a soilless mix as it reduces the risk of soilborne diseases caused by Fusarium, Phytophthora, Pythium, and Rhizoctonia and provides optimum

This work was supported by the College of Agriculture and Life Sciences at Iowa State University and the Leopold Center for Sustainable Agriculture.

The use of company name or product in this publication does not imply any kind of endorsement.

${ }^{1}$ Department of Horticulture, Iowa State University, 145 Horticulture Hall, Ames, IA 50011

${ }^{2}$ Horticulture Research Station, 55519 170th Street, Ames, IA 50011

${ }^{3}$ Corresponding author. E-mail: nairajay@iastate.edu. doi: 10.21273/HORTTECH03490-16 conditions for seedling growth. Seed germination and transplant growing medium is critical to transplant production as it provides proper $\mathrm{pH}$, aeration, and optimum water and nutrient retention for uniform seed germination and development of a healthy root system. Studies have shown that a high-quality transplant with a healthy root system has a positive effect on the vigor and productivity of the crop in the field (Leskovar and Stoffella, 1995).

Growers, whether they make their own growing medium or purchase it premixed, use medium that usually contains sphagnum peatmoss, vermiculite and/or perlite, and calcium carbonate. Sphagnum peatmoss often makes up greater than half the volume of the growing medium due to its ability to hold moisture while maintaining good pore space (Pill and Ridley, 1998; Schmilewski, 2008). Due to overwhelming use of sphagnum peatmoss in growing mixes, much research is now focused on finding environmentally friendly alternatives. Some alternatives to sphagnum peatmoss that have been investigated for their suitability in growing medium include coir, compost, bark, composted bark, and wood fiber (Schmilewski, 2008). Another alternative product that is being tested is biochar, but its potential impact on medium properties and seedling growth has not been tested and validated extensively.

Biochar is the term used for soil amendment made of charred organic matter and ash that remains after organic matter is thermally decomposed in a low-oxygen environment (Lehmann and Joseph, 2009). Biochar addition has been shown to impart beneficial chemical and physical attributes to mineral soils (Barrow, 2012; Laird, 2008). Benefits of adding biochar to soils include increased soil $\mathrm{pH}$ in low $\mathrm{pH}$ soils (Novak et al., 2009), increased retention of nutrients (Clough and Condron, 2010; Laird et al., 2010), and increased cation exchange capacity (Liang et al., 2006). Research on biochar as a component in soilless growing medium has been limited, although studies have focused on its suitability for nursery crops (Dumroese et al., 2011). Dumroese et al. (2011) evaluated pelletized biochar in combination with sphagnum peatmoss for production of forest seedlings. They found that amendment with $25 \%$ biochar pellets improved hydraulic conductivity and water retention at high matric potentials and beneficially increased medium

\begin{tabular}{llll}
\hline $\begin{array}{l}\text { Units } \\
\text { To convert U.S. to SI, } \\
\text { multiply by }\end{array}$ & U.S. unit & SI unit & $\begin{array}{l}\text { To convert SI to U.S., } \\
\text { multiply by }\end{array}$ \\
\hline 2.54 & inch $(\mathrm{es})$ & $\mathrm{cm}$ & 0.3937 \\
25.4 & inch $(\mathrm{es})$ & $\mathrm{mm}$ & 0.0394 \\
1 & $\mathrm{mmho} / \mathrm{cm}$ & $\mathrm{dS} \cdot \mathrm{m}^{-1}$ & 1 \\
28.3495 & $\mathrm{oz}$ & $\mathrm{g}$ & 0.0353 \\
0.0010 & $\mathrm{oz} / \mathrm{ft}^{3}$ & $\mathrm{~g} \cdot \mathrm{cm}^{-3}$ & 998.8379 \\
1 & $\mathrm{ppm}$ & $\mathrm{mg} \cdot \mathrm{kg}^{-1}$ & 1 \\
1 & $\mathrm{ppm}$ & $\mathrm{mg} \cdot \mathrm{L}^{-1}$ & 1 \\
$\left({ }^{\circ} \mathrm{F}-32\right) \div 1.8$ & ${ }^{\circ} \mathrm{F}$ & ${ }^{\circ} \mathrm{C}$ & $\left({ }^{\circ} \mathrm{C} \times 1.8\right)+32$
\end{tabular}


$\mathrm{pH}$. Studies have also focused on physical and chemical properties of biochar that contribute to retention of nutrients in soilless medium (Altland and Locke, 2012; Graber et al., 2010; Santiago and Santiago, 1989). Graber et al. (2010) reported positive effects of biochar on growth and productivity of pepper and tomato (Solanum lycopersicum) plants in a blend of coconut (Cocos nucifera) fiber and tuff (volcanic ash material). They reported that positive effects were mainly due to the presence of plant growth promoting and/or biocontrol agents present in biochar amended medium. In addition, they also cite the effect of low doses of biochar chemicals, many of which are phytotoxic or biocidal at high concentrations, to have stimulated plant growth at low doses (hormesis).

Studies have evaluated biochar to completely replace sphagnum peatmoss, use it for greenhouse production of mature plants, or transplant seedlings into biochar-amended medium. The influence of biochar in soilless medium on direct seeding of vegetable crops for transplant production has been studied less. This is important specially to understand effects biochar could have on seed germination. Germination assays to test the quality of biochar have been suggested as a means to evaluate biochar quality (Rogovska et al., 2012). In addition, the body of biochar research in soilless medium is far less complete with respect to identifying a suitable rate or concentration of biochar that could be used in vegetable transplant production. Also of particular interest is the transplant tray cell number, which is directly correlated with size of the transplant. Differences in transplant size resulting from differences in transplant tray cell number have been shown to affect stand establishment, earliness, yield, and quality (Nicola and Cantliffe, 1996). With the growing interest in replacing sphagnum peatmoss-based growing medium in greenhouse production systems, there is need to evaluate and assess use of hardwood-based biochar (described in materials and methods) in vegetable transplant production. The objectives of this study were to 1 ) determine the optimal amount of hardwood-based biochar that could be added to soilless peatmoss-based growing medium for pepper transplant production, 2) study the effect biochar on seed

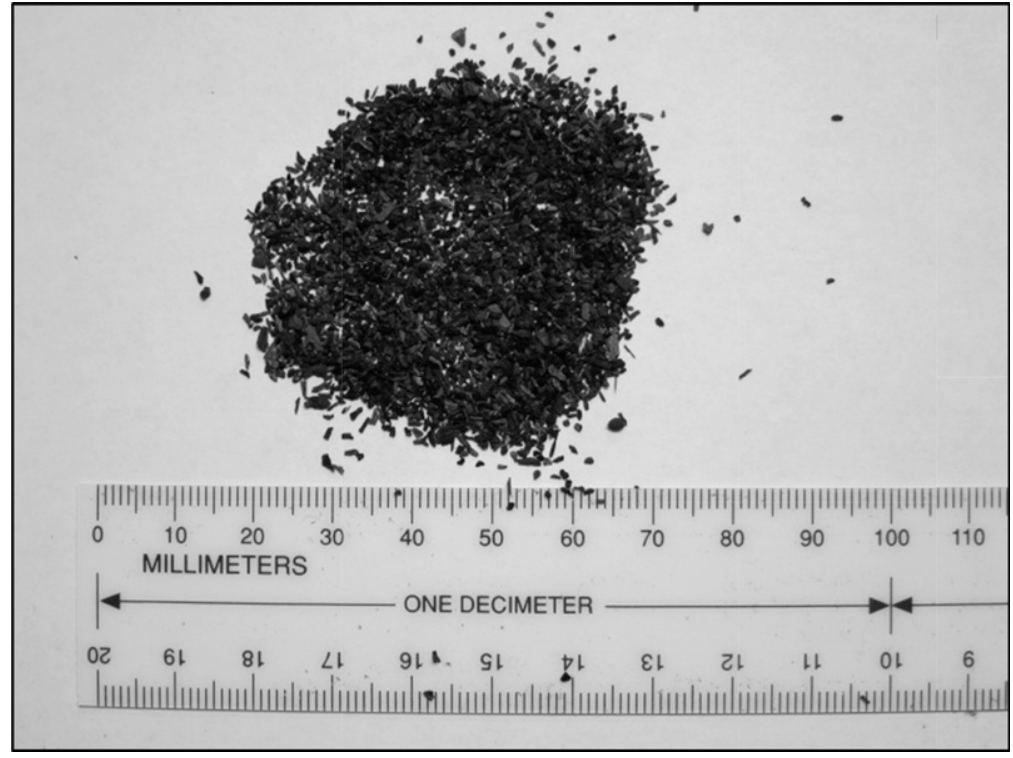

Fig. 1. The size of biochar used in this study. Biochar for this study was a commercial hardwood-based biochar produced primarily using oak, elm, and hickory in traditional kilns using slow pyrolysis at $842^{\circ} \mathrm{F}\left(450.0^{\circ} \mathrm{C}\right.$ ) (Royal Oak Charcoal, Roswell, GA); $1 \mathrm{~mm}=\mathbf{0 . 0 3 9 4}$ inch .

germination, plant growth, and growing medium chemical characteristics, and 3 ) determine if transplant tray cell number is an important factor when determining optimal biochar rates for transplant production.

\section{Materials and methods}

Biochar for this study was a commercial hardwood-based biochar produced primarily using oak (Quercus sp.), elm (Ulmus sp.), and hickory (Carya sp.) in traditional kilns using slow pyrolysis at $842{ }^{\circ} \mathrm{F}$ for $5-30 \mathrm{~min}$ (Royal Oak Charcoal, Roswell, GA). This process yields a char product that is high in carbon (C). The particle size of biochar was between 0.42 and $0.84 \mathrm{~mm}$ diameter and had a $\mathrm{C}$ : nitrogen $(\mathrm{N})$ ratio of $48: 1$ as determined by dry combustion analysis using a combustion analyzer (Vario MAX; Elementar Americas, Mt. Laurel, NJ) (Fig. 1). The bulk density of biochar was 0.28 $\mathrm{g} \cdot \mathrm{cm}^{-3}$ (Northup, 2013). Elemental composition of the biochar was determined by ashing at $1292{ }^{\circ} \mathrm{F}$, digestion of the ash in aqua regia, and analyzing using inductively coupled plasma-atomic emission spectroscopy. Total elemental composition of biochar is given in Table 1 . The three (cell number) by five (biochar concentration) factorial was arranged in a randomized complete block design with four replications. A standard commercial soilless sphagnum peatmoss-based
Table 1. Nutrient concentration of hardwood-based biochar (Royal Oak Charcoal, Roswell, GA) amended with soilless growing mix (Jiffy Mix ${ }^{\circledR}$ Growers Choice; Jiffy Products, Lorain, OH).

\begin{tabular}{lr}
\hline Nutrient & Concn $\left(\mathbf{m g} \cdot \mathbf{k g}^{-1}\right)^{\mathbf{z}}$ \\
\hline Phosphorus & 2,932 \\
Potassium & 35,920 \\
Sodium & 189 \\
Magnesium & 9,680 \\
Calcium & 382,800 \\
Manganese & 68 \\
Iron & 1,310 \\
Copper & 31 \\
Zinc & 106 \\
Aluminum & 1,251 \\
\hline
\end{tabular}

${ }^{\mathrm{z}} 1 \mathrm{mg} \cdot \mathrm{kg}^{-1}=1 \mathrm{ppm}$.

medium (Jiffy Mix ${ }^{\circledR}$ Growers Choice, Jiffy Products, Lorain, $\mathrm{OH}$ ) was used as the base medium for the study. The base medium was amended with biochar in following proportion on a by weight basis: $0 \%, 20 \%, 40 \%, 60 \%$, or $80 \%$. Water was added $(\approx 20 \%$ by volume) to the base medium and biochar blend and thoroughly mixed by hand in a large plastic tote. Hand mixing with water ensured a uniform mix and aided in the medium's ability to accept water. This medium was then filled into 50-, 72-, or 98-celled transplant trays (Blackmore Plastics, Bellville, MI). Pelleted 'Paladin' pepper seeds (Siegers Seed Co., Holland, MI) were seeded 
into trays on 8 Apr. 2012, and maintained in the greenhouse until 31 May 2012. The entire experiment was replicated twice and run simultaneously in two glass greenhouses. Temperature inside the greenhouse was maintained at $70{ }^{\circ} \mathrm{F}$ (day and night). Supplemental lighting was provided using highpressure sodium lamps starting 0600 to $2200 \mathrm{HR}$. Instantaneous light level at plant height measured during solar noon was $\approx 250 \mu \mathrm{mol} \cdot \mathrm{m}^{-2} \cdot \mathrm{s}^{-1}$.

The medium was kept moist until seed germination using tempered tap water $\left(66-70^{\circ} \mathrm{F}\right)$. All treatments were irrigated the same time every day, except the $80 \%$ biochar treatment, which was irrigated more frequently due to quicker drying of the medium. Starting $14 \mathrm{~d}$ after seeding, transplants were fertilized in the mornings during the normal irrigation schedule. Plants were fertilized $14,17,21,24,28,31,35,38,42$, and $45 \mathrm{~d}$ after seeding. Fertilization was achieved using water-soluble fertilizers (Peters Excel ${ }^{\circledR}$ Multi-Purpose and Cal-Mag; Everris International, Geldermalsen, the Netherlands). A final $\mathrm{N}$ concentration of $150 \mathrm{mg} \cdot \mathrm{L}^{-1}$ was used from 14 to $35 \mathrm{~d}$, after which the concentration of $\mathrm{N}$ was increased to $250 \mathrm{mg} \cdot \mathrm{L}^{-1}$.

Germination percentage was recorded $14 \mathrm{~d}$ after seeding. Data were collected on plant height, stem diameter, leaf chlorophyll content (SPAD$502 \mathrm{~m}$; Konica-Minolta, Osaka, Japan), and dry weight $56 \mathrm{~d}$ after seeding. Height, stem diameter, leaf chlorophyll content, and root and shoot dry weight were means of 10,12 , and 14 plants sampled from middle rows of 50-, 72-, and 98-celled trays, respectively. Height measurements were taken from the top of the medium to the growing point of each transplant. Stem diameter was measured just above the cotyledons using digital calipers (Fisher Scientific, San Diego, CA). Indirect measurement of leaf chlorophyll was recorded using a SPAD meter. On each plant, from the first recently mature leaf from the top, five SPAD readings were taken and averaged. Ten plants were sampled from each treatment. To determine total dry weight (root + shoot), roots were gently shaken to remove medium, washed, and cut at the medium line. Roots and shoots were then dried for $3 \mathrm{~d}$ at $150^{\circ} \mathrm{F}$ then weighed. Dry weight was taken on a precision balance (XE 510; Denver Instruments, Bohemia, NY). Growing medium was collected from plants used for dry weight analysis for $\mathrm{pH}$ and electrical conductivity (EC) measurements. EC and $\mathrm{pH}$ were measured using water:medium (2:1 volume) mixture with a handheld $\mathrm{pH} / \mathrm{EC}$ meter (HI 9813; Hanna Instruments, Woonsocket, $\mathrm{RI})$. Nitrate $\left(\mathrm{NO}_{3}\right)-\mathrm{N}$ was extracted using $2 \mathrm{~m}$ potassium chloride solution (Dahnke and Johnson, 1990).

Statistical analyses were conducted using SAS statistical software (version 9.3; SAS Institute, Cary, NC). Data from both greenhouses were pooled before analysis. An analysis of variance was conducted using type three sums of squares with the Satterthwaite approximation to compute degree(s) of freedom. The PROC MIXED procedure was used to determine means separation using "Ismeans" and "pdiff" statements in SAS $(P \leq 0.05$ level $)$.

\section{Results}

Seed germination. There was interaction between transplant tray cell number and biochar concentration $(P \leq 0.001)$ (Fig. 2). Germination in the 50-cell transplant tray was higher for $20 \%, 40 \%$, and $60 \%$ biochar treatments over the $0 \%$ and $80 \%$ treatments. A similar trend was observed in the 72-cell transplant tray. The lowest germination was recorded for $0 \%$ treatment in the 72-cell transplant tray. In the 98-cell treatment, there was no difference in germination between biochar concentration treatments.
SEEDLING HeIGHT. An analysis of variance showed a cell number by biochar interaction $(P \leq 0.001)$ with lower concentrations of biochar showing greater differences in height between cell numbers (Fig. 3A). Within the $0 \%, 20 \%$, and $40 \%$ biochar treatments, seedling height was highest for plants growing in the 50-cell tray. There was no difference in seedling height for plants growing in 72- and 98 -cell tray in the $0 \%$ biochar treatment. Within 20\%, 40\%, and 60\% biochar treatments, seedling height was higher for plants in 72-cell over 98-cell treatment. There was no difference in seedling height based on transplant tray cell number in the $80 \%$ biochar treatment.

Comparing seedling height within transplant tray cell number showed varying trends. In the 50-cell tray, there was no difference in seedling height between $0 \%, 20 \%$, and $40 \%$ biochar treatments; however, seedling height decreased when biochar concentration increased to $60 \%$ or $80 \%$ (Fig. 3A). Seedling height increased when biochar was added to the 72-cell tray, but that increase, with respect to $0 \%$ biochar treatment, was only seen when biochar was added at a $20 \%$ rate (Fig. 3 A). Additional increase of biochar did not increase seedling height; rather it reduced seedling height at $80 \%$ biochar concentration. There was no effect of biochar concentration on seedling height in the 98-cell tray up till $60 \%$ biochar concentration, after which

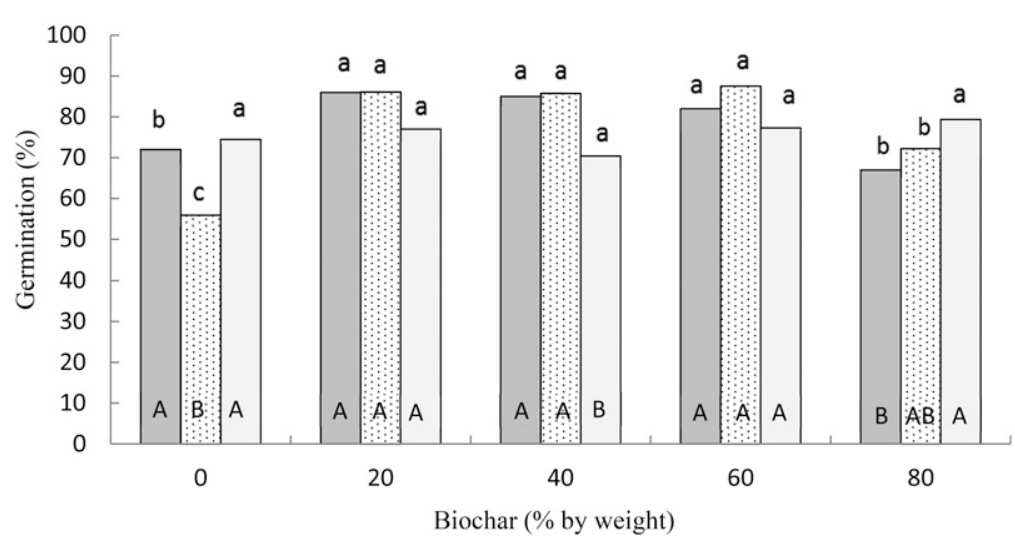

Fig. 2. Effect of biochar $(0 \%, 20 \%, 40 \%, 60 \%$, or $80 \%$ biochar by weight $)$ and transplant tray cell number (50-, 72-, or 98-cell trays) on pepper seed germination, collected 8 weeks after seeding. Means with different letters are significantly different (Fisher's protected least significant difference at $P \leq 0.05$ ). Lowercase letters indicate mean separation among biochar concentration within a particular tray cell number, whereas uppercase letters indicate mean separation among cell numbers within a particular biochar concentration. 

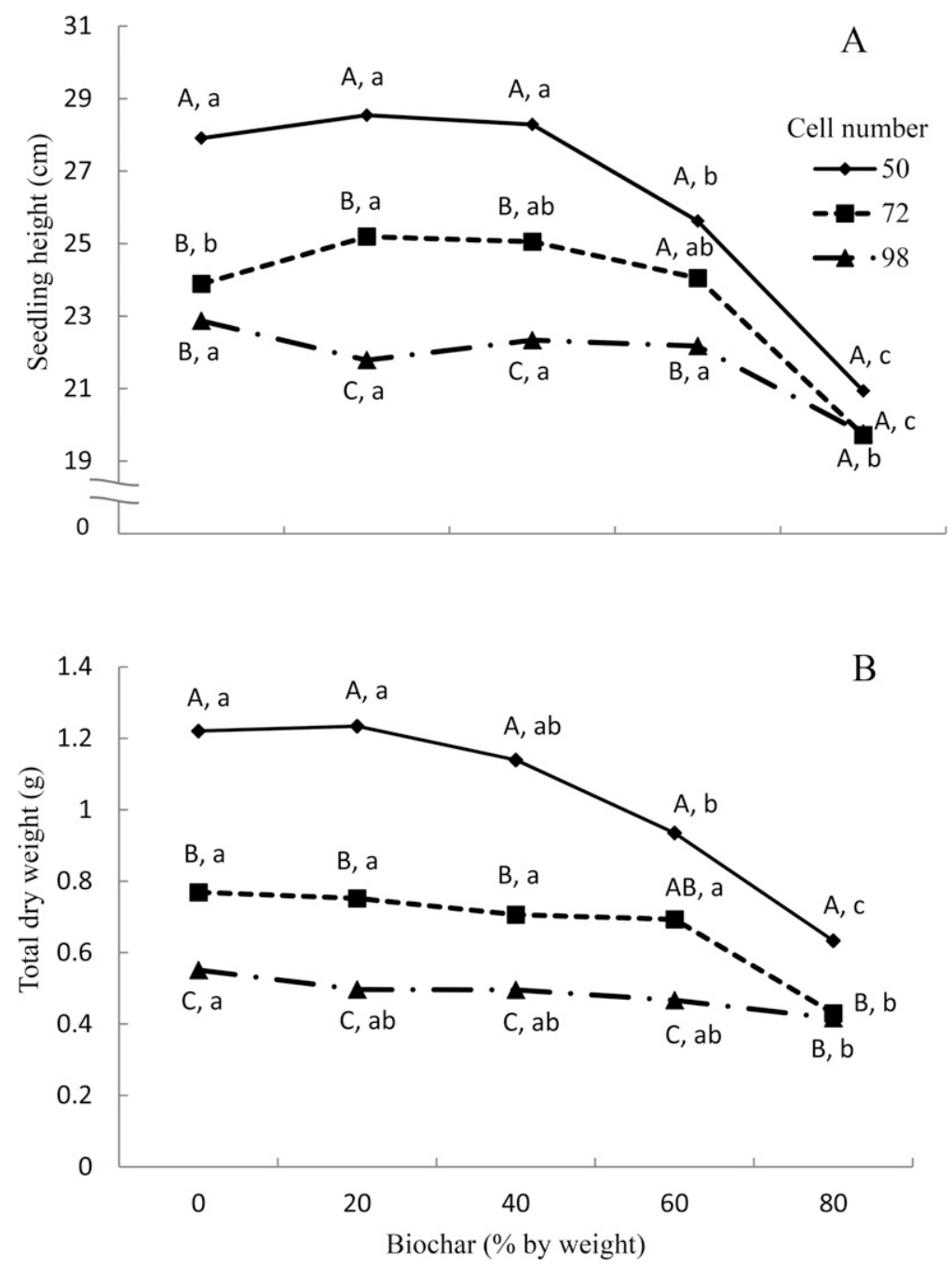

Fig. 3. Effects of cell number and biochar concentration on (A) plant height and (B) total dry weight. Uppercase letters and lowercase letters show mean separation between cell number and biochar concentration, respectively (Fisher's protected least significant difference at $P \leq 0.05) ; 1 \mathrm{~cm}=0.3937 \mathrm{inch}, 1 \mathrm{~g}=0.0353 \mathrm{oz}$.

seedling height decreased (Fig. 3A). Within all cell numbers, $80 \%$ biochar concentration significantly reduced seedling height.

DrY WEIGHT. There was a cell number by biochar interaction for total dry weight $(P \leq 0.003)$. Within $0 \%$, $20 \%$, and $40 \%$ biochar treatments, total transplant dry weight was always highest in the 50-cell treatment followed by 72 and 98-cell treatments (Fig. 3B). In 60\% biochar, dry weight was lowest in 98cell treatment. Dry weight in $80 \%$ biochar was highest in 50-cell treatment followed by 72 - and 98-cell treatments; however, there were no differences between latter treatments. Comparing dry weight within transplant tray cell number showed similar trends. Within 72and 98-cell number, there were no differences in total dry weight until $60 \%$ biochar treatment. When biochar concentration increased to $80 \%$, there was significant reduction in total dry weight, when compared with the $0 \%$ biochar treatment (Fig. 3B). Transplants growing in the 50-cell trays showed similar trend; however, differences showed up earlier starting at $60 \%$ biochar treatment. Within all cell numbers, total dry weight was lowest in the $80 \%$ biochar treatment when compared with the $0 \%$ biochar treatment.

ROOT:SHOOT RATIO AND STEM DIAMETER. No interaction was observed between transplant tray cell number and biochar concentration for root:shoot ratio or stem diameter. There were no significant differences for root:shoot ratio between cell numbers and biochar concentration treatments. Stem diameter decreased as transplant tray cell number increased (Table 2). Highest stem diameter was observed in the 50 -cell and the lowest in the 98-cell treatment. Stem diameter of transplants in $0 \%$ biochar treatment was higher than that of transplants growing in $40 \%, 60 \%$, or $80 \%$ treatment. There was no difference in stem diameter between $40 \%$ and $60 \%$ biochar treatments; however, when the concentration increased to $80 \%$, stem diameter decreased (Table 2). The lowest stem diameter was observed in the $80 \%$ biochar treatment.

Chlorophyll content. No interaction was observed between transplant tray cell number and biochar concentration for chlorophyll content, measured indirectly using SPAD meter. The SPAD value decreased as cell number increased (Table 2). Highest SPAD value was observed in the 50 -cell and the lowest in the 98-cell treatment. The highest SPAD value within biochar treatments was observed in $20 \%$ treatment, which was significantly higher than all other treatments. Transplants in the $80 \%$ biochar had lower SPAD values when compared with $0 \%, 20 \%$, or $40 \%$ treatment.

Medium pH And EC. Medium $\mathrm{pH}$ at the time of seeding was higher in the $80 \%$ biochar treatment; although this is not statistically proven, as the $\mathrm{pH}$ was measured on the original batch of medium, which was used to fill the cell trays. Four weeks after seeding, medium $\mathrm{pH}$ values increased with increasing levels of biochar (Table 3 ). The $80 \%$ biochar treatment showed a $\mathrm{pH}$ value of 8.0 , while the $0 \%$ showed 6.1. Similar differences in medium $\mathrm{pH}$ were observed 8 weeks after seeding. EC levels did not show differences until the end of the study ( 8 weeks after seeding). The $40 \%$ and $60 \%$ biochar treatments had higher electric conductivity levels than any other treatment (Table 3).

\section{Discussion}

Our results show that germination of pepper improved with $20 \%$, $40 \%$ or $60 \%$ biochar, when using 50 or 72-cell trays. This is a positive outcome but is specific to the type of biochar used in this study. An experiment assessing germination of corn (Zea mays) seeded in six different aqueous biochar extracts did not find significant differences in corn germination (Rogovska et al., 2012). It is difficult to compare results of that study with ours due to differences in biochar type and the medium used. 
We used a soilless medium, whereas Rogovska et al. (2012) used aqueous extracts for seed germination. In our study, the positive effect of biochar on seed germination was observed only up to a certain biochar rate. Germination percentage decreased when biochar concentration reached $80 \%$. This could be potentially due to the presence of polycyclic aromatic hydrocarbons (PAHs) in the biochar. Polycyclic aromatic hydrocarbons are recalcitrant, persistent, and phytotoxic compounds that can also be produced during the pyrolysis process and get adsorbed onto biochar surfaces (Sharma and Hajaligol, 2003). These PAHs have been shown to detrimentally affect seedling growth

(Rogovska et al., 2012). Even though the presence and relative abundance PAHs reported in the aqueous extract of a biochar similar to the one used in our study was low, the higher concentration of biochar in the $80 \%$ biochar could have raised PAH concentrations to detrimental levels. The scope of our study did not allow us to characterize and quantify types of PAHs and their concentrations. In addition, we observed enhanced drying of the growing medium with increasing biochar rates, with $80 \%$ biochar treatment drying the quickest. The $80 \%$ biochar treatment had $20 \%$ sphagnum peatmoss-based growing mix, while the $0 \%$ treatment was the growing mix in entirety.

Table 2. Pepper plant growth indicators 8 weeks after seeding in transplant trays (50-, 72-, or 98-cell trays) with biochar amended [0\%, $20 \%, 40 \%, 60 \%$, or $80 \%$ (by weight) soilless growing mix (Jiffy Mix ${ }^{\circledR}$ Growers Choice; Jiffy Products, Lorain, $\mathrm{OH})]$.

\begin{tabular}{lccc}
\hline & Root/shoot ratio & Stem diam $(\mathbf{m m})^{\mathrm{z}}$ & SPAD $^{\mathrm{y}}$ \\
\hline Cell number & & & \\
50 & $0.40^{\mathrm{Ns}}$ & $4.5 \mathrm{~A}^{\mathrm{x}}$ & $39.1 \mathrm{~A}$ \\
72 & 0.40 & $3.9 \mathrm{~B}$ & $37.3 \mathrm{~B}$ \\
98 & 0.39 & $3.5 \mathrm{C}$ & $36.3 \mathrm{C}$ \\
Biochar (\% by wt) & & \\
0 & $0.37^{\mathrm{Ns}}$ & $4.2 \mathrm{a}^{\mathrm{w}}$ & $38.2 \mathrm{~b}$ \\
20 & 0.39 & $4.1 \mathrm{ab}$ & $40.3 \mathrm{a}$ \\
40 & 0.39 & $4.0 \mathrm{~b}$ & $37.5 \mathrm{~b}$ \\
60 & 0.40 & $3.9 \mathrm{~b}$ & $36.5 \mathrm{bc}$ \\
80 & 0.43 & $3.6 \mathrm{c}$ & $35.3 \mathrm{c}$ \\
Significance & & & \\
& & & \\
Cell number & 0.868 & 0.0001 & 0.0003 \\
Biochar & 0.200 & 0.0010 & 0.0008 \\
Cell number $\times$ biochar & 0.095 & 0.0950 & 0.8790 \\
\hline
\end{tabular}

${ }^{\mathrm{z}}$ Stem diameter measured above the cotyledons; $1 \mathrm{~mm}=0.0394$ inch.

${ }^{y}$ Leaf chlorophyll measured using SPAD-502 Plus (Konica Minolta, Osaka, Japan).

${ }^{x}$ Means within columns with different uppercase letters are significantly different [Fisher's protected least significant difference (LSD) at $P \leq 0.05]$.

"Means within columns with different lowercase letters are significantly different (Fisher's protected LSD at $P \leq$ $0.05)$.

NS Nonsignificant at $P \leq 0.05$.

Table 3. Medium pH and electrical conductivity (EC) of biochar amended peat-based growing medium. Measurements were taken at 4-week intervals following a 2:1 water extraction method. Data collected from 72-cell tray treatment.

\begin{tabular}{|c|c|c|c|c|c|c|}
\hline \multirow{2}{*}{$\begin{array}{l}\text { Biochar } \\
(\% \text { by wt })\end{array}$} & \multicolumn{2}{|c|}{ At the time of seeding ${ }^{\mathrm{z}}$} & \multicolumn{2}{|r|}{$4 \mathrm{wk}$} & \multicolumn{2}{|r|}{8 wk } \\
\hline & $\mathrm{pH}$ & $\mathrm{EC}\left(\mathrm{dS} \cdot \mathrm{m}^{-1}\right)$ & $\mathrm{pH}$ & $\mathrm{EC}\left(\mathrm{dS} \cdot \mathrm{m}^{-1}\right)$ & $\mathrm{pH}$ & $\mathrm{EC}\left(\mathrm{dS} \cdot \mathrm{m}^{-1}\right)$ \\
\hline 0 & 5.2 & 0.84 & $6.1 \mathrm{e}^{\mathrm{y}}$ & 0.36 & $6.3 \mathrm{e}$ & $0.35 \mathrm{~b}$ \\
\hline 20 & 6.3 & 0.88 & $6.8 \mathrm{~d}$ & 0.36 & $7.1 \mathrm{~d}$ & $0.35 \mathrm{~b}$ \\
\hline 40 & 6.9 & 0.72 & $7.3 \mathrm{c}$ & 0.33 & $7.4 \mathrm{c}$ & $0.40 \mathrm{a}$ \\
\hline 60 & 7.4 & 0.32 & $7.7 \mathrm{~b}$ & 0.32 & $7.7 \mathrm{~b}$ & $0.40 \mathrm{a}$ \\
\hline 80 & 7.8 & 0.26 & $8.0 \mathrm{a}$ & 0.29 & $8.0 \mathrm{a}$ & $0.34 \mathrm{~b}$ \\
\hline
\end{tabular}

${ }^{\mathrm{z}}$ Measurements were taken from original mixture used to fill the cell trays (no replication); $1 \mathrm{dS} \cdot \mathrm{m}^{-1}=1 \mathrm{mmhos} / \mathrm{cm}$. ${ }^{y}$ Means within columns with different letters are significantly different (Fisher's protected least significant difference at $P \leq 0.05$ ).
Reduction in the proportion of peatbased growing mix could have resulted in lower water holding capacity, thus faster drying of the medium, which could have compounded germination issues.

In our study, transplant height decreased at higher biochar concentrations within individual cell numbers; however, $20 \%$ or $40 \%$ biochar treatments were not different from the $0 \%$ treatment. Graber et al. (2010) reported no difference in pepper plant height when grown in coconut coir-based medium amended with up to $5 \%$ biochar. Our study shows that pepper seedling height is unaffected as long as the biochar concentration is at or below $40 \%$; however, higher concentrations can reduce plant height. This could be due to negative effects of phytotoxic compounds present in the biochar. Shoot lengths of corn seedlings germinated in three aqueous biochar extracts were lower than those germinated in distilled water (Rogovska et al., 2012). This was attributed to higher concentration of water-soluble phytotoxic compounds in those biochar aqueous extracts. Pepper canopy dry weight increased when grown in coconut coir-based medium amended with $3 \%$ or $5 \%$ biochar (Graber et al., 2010). In our study, transplant dry weight for $20 \%, 40 \%$, or $60 \%$ biochar concentration was similar to the $0 \%$ in the 72 - or 98 -cell trays. This was similar to results reported by Northup (2013). Transplant dry weight decreased when the biochar concentration was $80 \%$ of the growing medium. This could be attributed to higher level of phytotoxic compounds (Rogovska et al., 2012) and/or lack of uniform water holding capacity in the $80 \%$ biochar treatment which affected overall transplant growth (Dumroese et al., 2011).

Both transplant height and dry weight decreased as transplant tray cell number increased. As the cell number of the transplant tray increases, it reduces the volume of individual cells in the tray. NeSmith and Duval (1998) reported that smaller plug cell volumes can reduce plant size and this reduction could be due to a number of factors. One possible factor could be competition between leaves for light and roots for oxygen. We speculate that increased plant density and reduced medium and root space per plant in the 98-celled tray may have contributed to lower 
nutrient retention, increased competition for light, as well as constriction of plant roots. In addition, it has been suggested that root restriction can reduce the photosynthesis efficiency of transplants (NeSmith and Duval, 1998). Reduction in plant height may have important implications in vegetable transplant production, especially considering that transplant producers use costly or labor intensive practices to decrease transplant height for automated transplanting (Garner and Björkman, 1996). Although our study shows that higher biochar concentration in the medium could reduce plant height, it is not desired, since higher concentrations also reduced transplant dry weight. Transplants with higher dry weight are often more vigorous, and have the ability to quickly overcome transplant shock, and provide higher productivity.

Stem diameter and indirect measurement of chlorophyll through SPAD decreased with increasing biochar concentration. This can be explained by two things, first, higher than optimal medium $\mathrm{pH}$ and, second, $\mathrm{N}$ tie up by biochar. The $40 \%, 60 \%$, and $80 \%$ biochar treatment had medium $\mathrm{pH}$ of 7.3 , 7.7 , and 8.0, respectively, 4 weeks after seeding. These levels of $\mathrm{pH}$ are not desirable for pepper transplant growth. Pepper seedlings prefer a medium $\mathrm{pH}$ between 5.5 and 6.8 (McAvoy and Ozores-Hampton, 2015). Additionally, high biochar concentrations could have affected plant growth by immobilizing $\mathrm{N}$ in the medium. Increased nitrate immobilization by biochar has been previously reported (Laird et al., 2010). Dumroese et al. (2011) reported immobilization of $\mathrm{N}$ in medium where $25 \%$ of the peat was replaced with biochar pellets. In our study, $\mathrm{NO}_{3}-\mathrm{N} 8$ weeks after seeding in the $0 \%, 20 \%, 40 \%, 60 \%$, and $80 \%$ media was $0.9,1.4,1.8,2.2$, and $2.9 \mathrm{mg} \cdot \mathrm{L}^{-1}$ respectively, indicating ability of biochar to hold on to N. It is has been reported that porous nature and large surface area associated with biochar, combined with different functional groups associated with these surface areas, combine to allow biochar to retain nutrients added to the soil (Major et al., 2009).

In our study, medium $\mathrm{pH}$ increased with increased biochar concentration. Dumroese et al. (2011) reported similar results when using pelletized biochar as a substrate in container nurseries. Results from our study clearly indicate that higher concentration of biochar is detrimental to plant growth, and one of the reasons is the increased $\mathrm{pH}$. Most vegetable transplants prefer medium $\mathrm{pH}$ between 5.8 and 6.8 , and higher concentration of biochar can increase $\mathrm{pH}$ way beyond 7.0 , as seen in this study. If using biochar as an ingredient in the growing medium, growers should regularly monitor medium $\mathrm{pH}$ and take corrective measures if $\mathrm{pH}$ is out of range.

In conclusion, our study demonstrates potential use of biochar for vegetable transplant production. Replacing $20 \%$ to $40 \%$ of sphagnum peatmossbased medium with biochar improved seed germination and positively influenced transplant growth; however, higher rates of biochar $(60 \%$ or $80 \%)$ reduced transplant growth. This research was conducted using an oak-based biochar produced by slow pyrolysis and the results are specific to this material. Similar products are available from other commercial sources; however, properties of biochar could significantly differ based on feedstock, pyrolysis temperature, and duration of pyrolysis. More research is needed to identify biochars made from different feedstocks that can positively influence transplant growth and contribute to efficient and sustainable transplant production. Currently in the United States, the number of biochar manufacturers is limited, leading to relatively high cost as compared with sphagnum peatmoss-based products; however, environmental sustainability, increasing cost of sphagnum peatmossbased growing medium, and grower interest in using environmentally friendly products, will lead to increased production and reduction in biochar costs.

\section{Literature cited}

Altland, J.E. and J.C. Locke. 2012. Biochar affects macronutrient leaching from a soilless substrate. HortScience 47:1136-1140.

Barrow, C.J. 2012. Biochar: Potential for countering land degradation and for improving agriculture. Appl. Geogr. 34:21-28.

Biai, C.J., J.A. Osborne, J.R. Schultheis, R.J. Gehl, and C.C. Gunter. 2011. Height control in three pepper types treated with drench-applied abscisic acid. HortScience 46:1265-1269.

Clough, T.J. and L.M. Condron. 2010. Biochar and the nitrogen cycle: Introduction. J. Environ. Qual. 39:1218-1223.
Dahnke, W.C. and G.V. Johnson. 1990. Testing soils for available nitrogen, p. 127-139. In: R.L. Westerman (ed.). Soil testing and plant analysis. Soil Sci. Soc. Amer., Madison, WI.

Dumroese, R.K., J.H. Heiskanen, K. Englund, and A. Tervahauta. 2011. Pelleted biochar: Chemical and physical properties show potential use and a substrate in container nurseries. Biomass Bioenergy 35:2018-2027.

Garner, L.C. and T. Björkman. 1996. Mechanical conditioning for controlling excessive elongation in tomato transplants: Sensitivity to dose, frequency, and timing of brushing. J. Amer. Soc. Hort. Sci. 121:894-900.

Graber, E.R., Y.M. Harel, M. Kolton, E. Cytryn, A. Sibler, D.R. David, L. Tsechansky, M. Borenshtein, and Y. Elad. 2010. Biochar impact on development and productivity of pepper and tomato grown in fertigated soilless media. Plant Soil 337:481-496.

Laird, D.A. 2008. The charcoal vision: A win-win-win scenario for simultaneously producing bioenergy, permanently sequestering carbon, while improving soil and water quality. Agron. J. 100:178-181.

Laird, D.A., P.D. Fleming, D.L. Karlen, B. Wang, and R. Horton. 2010. Biochar impact on nutrient leaching from a midwestern agricultural soil. Geoderma 158:436-442.

Lehmann, J. and S. Joseph. 2009. Biochar for environmental management: An introduction, p. 1-12. In: J. Lehmann (ed.). Biochar for environmental management. Earthscan, London, UK/Washington, DC.

Leskovar, D.I. and P.J. Stoffella. 1995. Vegetable seedling root systems: Morphology, development, and importance. HortScience 30:1153-1159.

Liang, B., J. Lehmann, D. Solomon, J. Kinyangi, J. Grossman, B. O’Neill, J.O. Skjemstad, J. Thies, F.J. Luizao, J. Petersen, and E.G. Neves. 2006. Black carbon increases cation exchange capacity in soils. Soil Sci. Soc. Amer. J. 70:1719-1730.

Major, J., C. Steiner, A. Downie, and J. Lehmann. 2009. Biochar effects on nutrient leaching, p. 272-285. In: J. Lehmann (ed.). Biochar for environmental management. Earthscan, London, UK/Washington, DC.

McAvoy, G. and M. Ozores-Hampton. 2015. Commercial transplant production in Florida. Univ. Florida, Inst. Food Agr. Sci. Publ. HS714.

NeSmith, D.S. and J.R. Duval. 1998. The effect of container size. HortTechnology 8:495-498. 
Nicola, S. and D.J. Cantliffe. 1996. Increasing cell size and reducing medium compression enhance lettuce transplant quality and field production. HortScience 31:184-189.

Northup, J. 2013. Biochar as a replacement for perlite in greenhouse soilless substrates. MS Thesis, Iowa State Univ., Ames, IA.

Novak, J.M., W.J. Busscher, D.L. Laird, M. Ahmedna, D.W. Watts, and M.A.S. Niandou. 2009. Impact of biochar amendment on fertilityof a southeastern coastal plain soil. Soil Sci. 174:105-112.
Pill, W.G. and K.T. Ridley. 1998. Growth of tomato and coreopsis in response to coir dust in soilless media. HortTechnology 8:401-406.

Rogovska, N., D. Laird, R.M. Cruse, S. Trabue, and E. Heaton. 2012. Germination tests for assessing biochar quality. J. Environ. Qual. 41:1014-1022.

Santiago, A. and L.A. Santiago. 1989. Charcoal chips as a practical substrate for container horticulture in the humid tropics. Acta Hort. 238:141-147.

Schmilewski, G. 2008. The role of peat in assuring the quality of growing media. Mires Peat 3(2):1-8.
Schrader, W.L. 2000. Using transplant in vegetable production, Univ. California, Div. Agr. Natural Resources Publ. 8013.

Sharma, R.K. and M.R. Hajaligol. 2003. Effect of pyrolysis conditions on the formation of polycyclic aromatic hydrocarbons (PAHs) from polyphenolic compounds. J. Anal. Appl. Pyrolysis 66:123-144.

U.S. Department of Agriculture. 2016. Vegetables 2015 summary. 11 July 2016. $<$ http://usda.mannlib.cornell.edu/ usda/current/VegeSumm/VegeSumm02-04-2016.pdf>. 